\title{
Association of functional limitations and disability with elder abuse in India: a cross- sectional study
}

\author{
T. Sathya ${ }^{1 *}$ and Ramaswamy Premkumar ${ }^{2}$
}

\begin{abstract}
Background: Globally, elder abuse is a common form of violence against the elderly. This study examines the association of disability and functional ability measures with elder abuse in India.

Methods: Cross-sectional data from the UNFPA's 'Building Knowledge Base on Population Ageing in India' (BKPAI 2011) have been analysed. Bivariate and multivariate logistic regression analyses have been used to examine the association of measures of disability and functional ability with elder abuse/mistreatment.

Results: The overall prevalence of elder abuse in the study population is $11.4 \%$. The prevalence of elder abuse experienced by study participants in the month before the survey is $6 \%$. The prevalence of disability/functional ability increases the likelihood of elder abuse. Furthermore, the association between functional ability and abuse is stronger and consistent among the elderly who experienced abuse in the month preceding the survey. In addition, the association between disability and elder abuse is stronger in urban areas. Another observation is that gender introduces considerable disparities in the association of disability and functional ability measures with elder abuse. While elderly men with more than two disabilities are 1.85 times (95\% Cl: $1.23,2.77, p<0.003$ ) more likely to experience abuse/mistreatment, women are 3.16 times (Cl: 2.22, 4.49, $p<.001)$ more exposed to it.

Conclusions: The results of this study suggest a significant association of disability and functional ability with elder abuse. The association differs considerably by place of residence and gender. Measures to improve the functional health of the elderly population and measures to protect the elderly with disability and functional limitations are important in preventing abuse/mistreatment in old age.
\end{abstract}

Keywords: Elder abuse, Disability, Functional ability, India

\section{Background}

The World Health Organization (2008) defines elder abuse as 'a single, or repeated act, or lack of appropriate action, occurring within any relationship where there is an expectation of trust which causes harm or distress to an older person [1].' Elder abuse varies in form and severity. It includes physical, sexual and verbal ill

\footnotetext{
*Correspondence: sathya@iips.net

'Department of Development Studies, International Institute for Population Sciences, Govandi Station Road, Mumbai 400088, India

Full list of author information is available at the end of the article
}

treatment as well as financial exploitation and neglect [2]. Elder abuse is sometimes called elder mistreatment or elder maltreatment [3].

Elder abuse has significantly adverse consequences for the health and well-being of the older population. Elder abuse leads to psychological distress and depression [4-6], mortality [7-9] and hospitalization [10]. The association between elder abuse and mortality is mainly driven by depression and lower levels of social engagement [8]. Furthermore, abuse or mistreatment in old age reduces quality of life $[11,12]$ as well as subjective well-being [13].

C C The Author(s). 2020 Open Access This article is licensed under a Creative Commons Attribution 4.0 International License, which permits use, sharing, adaptation, distribution and reproduction in any medium or format, as long as you give appropriate credit to the original author(s) and the source, provide a link to the Creative Commons licence, and indicate if changes were made. The images or other third party material in this article are included in the article's Creative Commons licence, unless indicated otherwise in a credit line to the material. If material is not included in the article's Creative Commons licence and your intended use is not permitted by statutory regulation or exceeds the permitted use, you will need to obtain permission directly from the copyright holder. To view a copy of this licence, visit http://creativecommons.org/licenses/by/4.0/ The Creative Commons Public Domain Dedication waiver (http://creativecommons.org/publicdomain/zero/1.0/) applies to the data made available in this article, unless otherwise stated in a credit line to the data. 
Globally, elder abuse is a common form of violence against the elderly which has significant implications on public policy. A meta-analysis consisting of data from 28 countries has reported $15.7 \%$ prevalence of elder abuse [14]. Several studies have identified major correlates of elder abuse, which include age, living arrangement, socioeconomic status and health [15-19]. Health emerges as an important and modifiable risk factor of elder abuse. Frailty is also closely linked with it [20, 21]. Mental health conditions such as depression, dementia and cognitive impairment are also significantly associated with elder abuse [22-27]. Poor functional capacity increases the risk of dependency thereby the risk of elder abuse increases. Previous tudies mainly from high-income countries have observed a significant relationship between functional ability/disability and elder abuse [19, 28-33]. A systematic review has identified functional dependence or disability as a strong risk factor of elder abuse [26]. Additionally, a metaanalysis has highlighted the differences in the prevalence of elder abuse among general population and elder with disabilities, which suggests higher prevalence of abuse among elderly with disabilities [14]. They have found that elderly persons with disability or functional limitations are at high risk of being victims of abuse because of their dependence on caregivers [30, 33-36]. Some of the risk factors related to elder abuse are cognitive and functional impairments [16], which place additional demands on caregivers [37]. Studies have shown the prevalence of abuse if caregivers are required to devote more time, particularly to elders suffering from dementia [38]. Dementia significantly increases elder abuse by caregivers due to the spending of more time with elder persons [22, 39].

In old age functional independence is an important characteristic of healthy ageing [40]. Functional limitations and disability conditions are linked to higher utilization of healthcare, lower levels of social cohesion and poor mental health status. As a result of functional limitations, the elderly are more likely to depend on others for fulfilling their basic needs Person needs assistance or adaptive equipment when he/she is faces limitations in physical capacity [30]. The functional disability is the inability or difficulty in performing everyday tasks of human beings, which are usually necessary for an independent life in social environment [41]. Moreover, elderly with functional disability greater need of help in self-care activities and more complex everyday activities and this is directly associated with elder abuse due to dependency [30]. Overall, very few studies have examined the association of health conditions such as depression, poor self-rated health and chronic diseases with elder abuse in India [15, 42-44]. However, the association of disability and functional limitations with elder abuse is less known in India.

Understanding the association of functional ability/disability with elder abuse will be useful in the context of population ageing in India. In 2011, the share of the $60+$ population in India was $8.2 \%$, which is estimated to increase to $19.4 \%$ by 2050 [45]. Increasing age is closely associated with higher risk of disabilities and low functional abilities. In this context, it is necessary to inform the policymakers about the role of functional ability and disability in determining elder abuse. In this study, we examine the association between functional ability/disability with elder abuse in India using a nationally representative data of elderly age 60 and above. We also examine to what extent the association between disability and elder abuse differs by gender and place of residence (rural/urban).

\section{Methods}

Data

United Nations Population Fund (UNFPA)'s survey namely Building a Knowledge Base on Population Ageing in India (BKPAI), 2011 dataset has been used to fulfill the objectives of this study. BKPAI was an initiative to fill the knowledge gap on population ageing in India. The information gathered in this survey includes socioeconomic status; work participation and benefits; income and asset holding; living arrangement patterns and familial relations; social activities; abuse experience and nature of abuse; health status; utilisation and financing of healthcare; and reach and awareness of social security schemes among the elderly.

BKPAI was a nationally representative survey which collected data from sevenmajor demographically advanced states of India such as Himachal Pradesh, Kerala, Maharashtra, Odisha, Punjab, Tamil Nadu and West Bengal that have a higher percentage of the population in the age group 60 years and above compared to the national average. While all survey states are demographically advanced than the national average, within this sample there are significant variations in per-capita income and demographic development. The states of Punjab and Maharashtra are economically advanced states, whereas Orissa is one of the poorest states in the country. Kerala has the highest share of elderly population but also developed socio-demographic indicators [18]. The sample for each state was fixed at 1280 elderly households. From these selected households, those households that had at least one elderly member aged 60 years or above from the set of sample household and all the elderly members in the selected households were interviewed. A total of 8329 household interviews and 9852 elderly interviews were conducted in both rural and urban areas. The sample size was equally divided between urban and rural areas, irrespective of the proportion of urban and rural population. Eighty Primary Sampling Units (villages or urban wards) - 40 urban and an equal number of rural - with 16 households per 
Primary Sampling Unit (PSU) having an elderly person were covered in the survey. The urban and rural samples within each state were drawn separately. The PSUs in the rural areas were villages, whereas the urban wards were the PSUs in the urban areas [46].

\section{Outcome variable}

\section{Elder abuse (ever)}

In the BKPAI survey, respondents were asked a question regarding their experience of abuse since they turned 60 years and in the previous month. The question was, 'In the time since you completed 60 years of age have you faced any type of abuse or violence or neglect or disrespect by any person? 'The respondents answered 'yes' or 'no'.

\section{Current experience of abuse (last 1 month)}

Those who reported ever experiencing abuse were asked an additional question about the experience of abuse in the previous month. The question was, 'Have you faced any physical or emotional abuse or violence in the last 1 month?' A dichotomous variable was generated by taking those who said to the above question as 'yes' and those who never experienced abuse as 'no'.

\section{Main predictors \\ $A D L$ and IADL limitations}

Data on six ADLs (activities of daily living) limitations was collected: bathing, dressing, toilet, mobility, continence and feeding. A single variable of ADL was generated by combining these six ADL and was recoded as 'no ADL', '1 ADL' and '2+ ADLs. Similarly, a single variable of IADL (instrumental activities of daily living) limitations was generated by combining eight variables that included difficulty in using the telephone, shopping, preparing food, housekeeping, doing laundry, arranging transportation, handling medication and finances. These were recoded as 'no IADL', '1 IADL' and '2+ IADLs'.

\section{Disability}

In the BKPAI survey, information on self-reported prevalence of disability was collected with the following question: 'Do you have any of the following difficulties?' Data on six types of disabilities was collected, namely vision, hearing, walking, teeth (chewing), speaking and memory. A single variable was generated by combining all the disability measures and recoded as 'no disability', ' 1 disability' and ' $2+$ disabilities'.

\section{Socio-demographic characteristics}

Age group (60-69, 70-79 and 80+), marital status (currently married and widowed/separated/divorced), place of residence (rural/urban), caste (Scheduled Caste or Scheduled Tribe (SC/ST), Other Backward Caste' (OBC) and Others), religion (Hindu, Muslim, Sikh, and Others), years of schooling ( $0-4$ years, 5-9 years and $10+$ years), wealth quintile (poorest, poorer, middle, richer and richest).

\section{Statistical analysis}

Bivariate analysis has been carried out to understand the sample distribution and the prevalence of elder abuse by disability and functional limitations. Logistic regression has been used to examine the association of sociodemography and disability/functional limitations with elder abuse. The regression analysis has been stratified by gender and place of residence to better understand the difference in association across male, female, rural and urban. All statistical analyses have been performed using STATA 12 (StataCorp, LP, College Station, Texas).

\section{Results}

Table 1 describes the characteristics of the study population. The overall prevalence of elder abuse in the study population is $11.4 \%$. The prevalence of elder abuse experienced by study participants in the month before the survey is $6 \%$. In this study, the percentage of older adults with no disability is 82.1 , while those with at least one disability is $12.6 \%$. The share of women participants (52.6) is higher in the total sample and a higher share of study participants is from rural areas (73.5\%). About $60 \%$ of the study population is currently married. While $3 \%$ of study participants have reported difficulties in any one ADL, $4.79 \%$ have reported difficulties in two or more than two ADLs. The percentage of elderly with 1+ IADL is 72.5. About two-thirds of study participants have had only $0-4$ years of schooling.

Figure 1 shows the prevalence of elder abuse by ADL and IADL limitations and disability conditions. The prevalence of elder abuse is $9.4 \%$ among the elderly with no ADL limitations and increases to $14.9 \%$ with $2+\mathrm{ADL}$ limitations. The prevalence of abuse in last 1 month increases with ADL, IADL and disability conditions. Similarly, the elderly with no IADL limitations have lower prevalence of elder abuse of $6.4 \%$, which increases to $11 \%$ for the elderly with $2+$ IADLs. The prevalence of elder abuse with disability increases from $17.2 \%$ for elderly with one disability to $21.4 \%$ with $2+$ disabilities. Similarly, the prevalence of abuse in last 1 month increases with ADL, IADL and disability conditions.

Table 2 shows the logistic regression results of elder abuse in relation to disability and functional limitations along with socio-demographic characteristics. The association between disabilities and elder abuse is positive and significant. The elderly with $2+$ disabilities are 2.47 times more likely to experience abuse $[\mathrm{CI}=1.90,3.21$, $p<.001$ ]. Similarly, the elderly with $2+$ ADLs are $40 \%$ more likely to experience abuse. The association of disability and functional ability with abuse in the month 
Table 1 Characteristics of the study population, BKPAI, 2011

\begin{tabular}{|c|c|c|}
\hline Characteristics & Categories & Percent \\
\hline \multirow[t]{2}{*}{ Abused since 60 years old } & No & 88.6 \\
\hline & Yes & 11.4 \\
\hline \multirow[t]{2}{*}{ Abused in Last one Month } & No & 94.79 \\
\hline & Yes & 6.02 \\
\hline \multirow[t]{3}{*}{$\mathrm{ADL}$} & No & 92.37 \\
\hline & $1 \mathrm{ADL}$ & 2.83 \\
\hline & $2+\mathrm{ADL}$ & 4.79 \\
\hline \multirow[t]{3}{*}{ IADL } & No IADL & 12.03 \\
\hline & $1 \mathrm{IADL}$ & 15.45 \\
\hline & $2+\mid A D L$ & 72.52 \\
\hline \multirow[t]{3}{*}{ Disability } & No disability & 82.13 \\
\hline & 1 disability & 12.58 \\
\hline & $2+$ disability & 5.29 \\
\hline \multirow[t]{3}{*}{ Age } & $60-69$ & 61.85 \\
\hline & $70-79$ & 27.3 \\
\hline & $80+$ & 10.85 \\
\hline \multirow[t]{2}{*}{ Sex } & Male & 47.33 \\
\hline & Female & 52.67 \\
\hline \multirow[t]{2}{*}{ Marital status } & Married & 60.34 \\
\hline & Others & 39.66 \\
\hline \multirow[t]{2}{*}{ Residence } & Rural & 73.57 \\
\hline & Urban & 26.43 \\
\hline \multirow[t]{3}{*}{ Caste } & $\mathrm{SC} / \mathrm{ST}$ & 26.37 \\
\hline & $\mathrm{OBC}$ & 36.71 \\
\hline & Others & 36.92 \\
\hline \multirow[t]{4}{*}{ Religion } & Hindu & 78.25 \\
\hline & Muslim & 8.34 \\
\hline & Sikh & 9.15 \\
\hline & Others & 4.26 \\
\hline \multirow[t]{3}{*}{ Schooling } & $0-4$ years & 64.43 \\
\hline & $5-9$ years & 20.46 \\
\hline & $10+$ years & 15.1 \\
\hline \multirow[t]{5}{*}{ Wealth quintile } & Poorest & 24.25 \\
\hline & Second & 22.14 \\
\hline & Middle & 20.46 \\
\hline & Fourth & 18.36 \\
\hline & Richest & 14.79 \\
\hline \multirow[t]{7}{*}{ State } & Himachal Pradesh & 15.03 \\
\hline & Punjab & 13.92 \\
\hline & West Bengal & 12.94 \\
\hline & Orissa & 15.03 \\
\hline & Maharashtra & 14.57 \\
\hline & Kerala & 13.86 \\
\hline & Tamil Nadu & 14.66 \\
\hline
\end{tabular}

preceding the survey was consistent and significant. The elderly with $2+$ IADLs and disability were two times more likely to experience abuse. Similarly, the elderly with 2+ ADLs had an 83\% higher risk of experiencing abuse in the preceding month. The association between marital status and abuse significant only those who ever experienced (Abused since 60 years old). Currently married elders have lower risks of abuse than others [OR = $1.24, \mathrm{CI}=1.05,1.48, p<.001]$. Socioeconomic status is negatively associated with elder abuse. The elderly individual with $10+$ years of schooling is less likely to experience abuse in last 1 month as well as ever experience of abuse (since 60 years old). The association between wealth quintile and elder abuse is highly significant across measures of abuse. The elderly in the richest wealth quintile are $70 \%$ less likely to experience abuse (since 60 years old) $[\mathrm{CI}=0.22,0.40, p<.001]$ and abuse in last 1 month $[\mathrm{CI}=0.18,0.48, p<.001]$. The elderly in Maharashtra are more likely to experience abuse than those in Himachal Pradesh. On the other hand, the elderly in West Bengal, Odisha, Kerala and Tamil Nadu are less likely to experience abuse as compared to those in Himachal Pradesh. In particular, the prevalence of abuse in the month preceding the survey was 23 times higher in Maharashtra.

Table 3 shows the logistic regression results of elder abuse stratified by gender. The association with elder abuse of disability, functional limitations and years of schooling differs considerably by gender. The association of disability with elder abuse is significantly stronger for women than for men. Elderly women with one disability are 2.18 times more likely to experience abuse $[\mathrm{CI}=$ $1.68,2.84, p<.001]$ and those with $2+$ disabilities are 3.16 times more likely to experience abuse (abused since 60 years old) $[\mathrm{CI}=2.22,4.49, p<.001]$. The association between IADL and abuse (abused since 60 years old) significant only for women. Similarly, elderly women with $2+$ disabilities were three times more likely to experience abuse in the month before the survey $[p<.001]$. Elderly men and women with IADL limitations had higher risk of abuse in this period. However, the association between ADL limitations and abuse in last 1 month is significant only for men. The positive association between age $(80+)$ and abuse (abused since 60 years old) is significant only for men.

The association between marital status and elder abuse is significant for women. Elderly women with $10+$ years of education have less likelihood of experiencing abuse. The association between wealth quintile and elder abuse is highly significant and negative for both men and women. Elderly men and women in the richest wealth quintile are less likely (up to $70 \%$ ) to experience abuse across two measures (abused since 60 years old and in last 1 month). Table 4 shows the logistic regression 


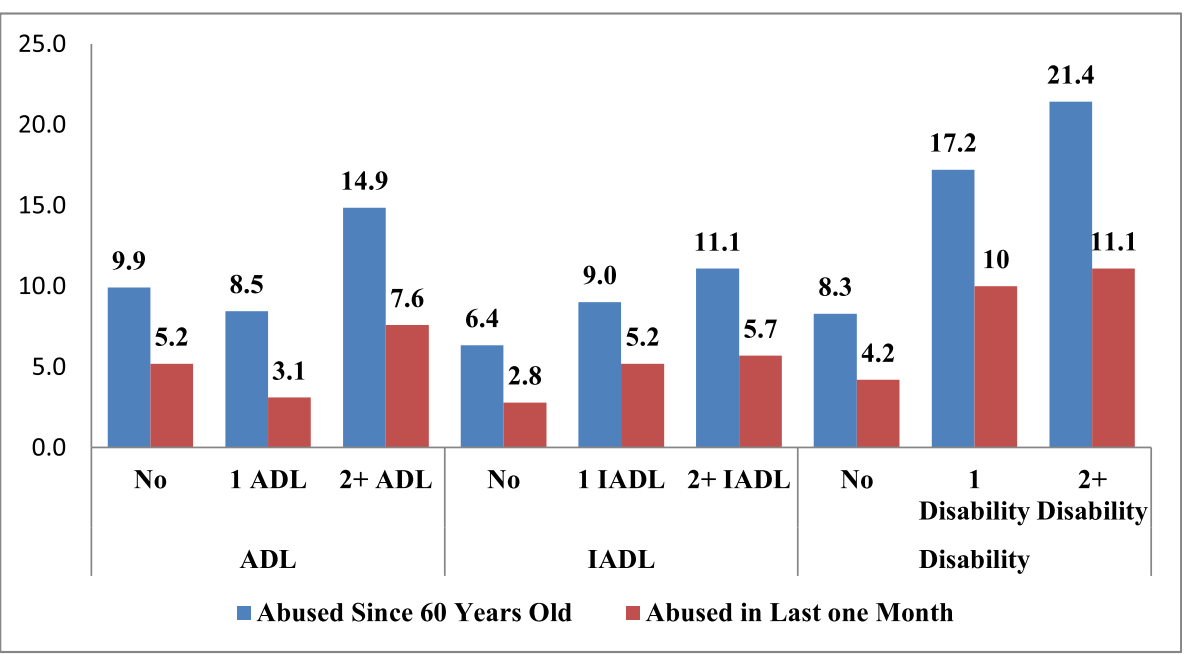

Fig. 1 Prevalence of elder abuse by ADL, IADL and disabilities, BKPAI

results of ever experiencing abuse and abuse experienced in the month before the survey by place of residence. The association between disability and abuse differs considerably for urban and rural areas. A strong evidence of higher risk of abuse is observed among the elderly in urban areas with disability. The elderly in urban areas with $2+$ disabilities are three times more likely to experience abuse since 60 years old $[\mathrm{OR}=3.49, \mathrm{CI}=2.38,5.13$, $p<.001]$. Whereas, elderly residing in rural areas with $2+$ disabilities are 1.85 times more likely to experience elder abuse since 60 years old $[\mathrm{CI}=1.28,2.67, p<.001]$. The elderly in rural areas with $2+$ ADL limitations had higher risk of abuse in the month preceding the survey. The association between IADL and abuse (in last 1 month) is significant in rural and urban areas. Religion and marital status is significant only in rural areas. The association between education and elder abuse is significant only in urban areas. The elderly in the richest wealth quintile category have less likelihood of experiencing abuse in both rural and urban areas.

\section{Discussion}

This study examines the relationship of disability and functional limitation with mistreatment/abuse among the elderly using a nationally representative data of the elderly population in India. It also assesses the differences in the association by gender and place of residence. Findings reveal that the prevalence of abuse increases with functional limitations and disability. The regression results suggest a significant relationship between disability/functional limitations and elder abuse. In particular, the association between disability and elder abuse is stronger than ADL and IADL limitations. Furthermore, the results differ considerably for the conditions of ever having experienced abuse and having experienced abuse in the month preceding the survey. The association is slightly stronger and consistent across functional ability measures (ADL and IADL) for the elderly who experienced abuse in the month before the survey. Additionally, the association is stronger for women and urban residents.

In this study, the association of disability/functional limitations and sociodemographic variables with elder abuse differ by ever experience of abuse and having experienced abuse in the month preceding the survey. Factors such as disability/functional limitations, caste and schooling is associated with elder abuse across two time period. Marital status and caste significant only among those who experienced abuse since 60 years old. The association of schooling and poor self-rated health with elder abuse/mistreatment is significant only in urban areas. On the other hand, marital status, caste, religion, tobacco use were associated with elder abuse/mistreatment in rural areas.

Previous literature has indicated that health factors such as disabilities, dementia and chronic diseases are associated with elder abuse. More specifically, conditions like dementia and frailty are closely associated with elder abuse suggesting the role of situationnel approach theory that hypothesizes the overburden on caregivers resulting in higher degrees of abuse $[16,22]$. In this study, the prevalence of disability conditions and functional limitations are positively associated with elder abuse/ill-treatment as consistent with literature [19, 28-33]. Previous literature has shown that disability in old age is associated with long-term care and care dependence [47] as well higher healthcare expenditure [48]. This in turn may lead to caregivers and family members abusing their elders. Elders with disabilities and functional limitations find it difficult to carry out day-to-day activities 
Table 2 Logistic regression results of disability and functional health with elder abuse, BKPAl, 2011

\begin{tabular}{lll}
\hline Characteristics & $\begin{array}{l}\text { Abused since } \\
60 \text { years old }\end{array}$ & $\begin{array}{l}\text { Abused in last } \\
\text { one month } \\
\text { OR }(95 \% \mathrm{Cl})\end{array}$ \\
& OR $(95 \% \mathrm{Cl})$
\end{tabular}

ADL

No ADL

$1 \mathrm{ADL}$

$2+\mathrm{ADL}$

IADL

No IADL
1 IADL
$2+\mid A D L$

Disability

No disability

1 disability

$2+$ disability

Age

\section{0-69 \\ 70-79}

$80+$

Sex

Male
Female

Marital status

Married

Others

Residence

Rural

Urban

\section{Caste}

$\mathrm{SC} / \mathrm{ST}$

Others

Religion

Hindu

Muslim

Sikh

Others

\section{Schooling}

0-4 years

5-9 years

$10+$ years

Wealth quintile

Poorest

Second

Middle

$$
\begin{aligned}
& \text { Ref } \\
& 1.00[0.61,1.64]
\end{aligned}
$$

$1.31 *[0.96,1.80]$

Ref

$1.28[0.94,1.74]$

$1.40^{* *}[1.07,1.83]$

Ref

$1.93^{* * *}[1.59,2.34]$

$2.47^{* * *}[1.90,3.21]$

Ref

$0.9[0.75,1.07]$

$1.14[0.89,1.45]$

Ref

$0.93[0.78,1.10]$

Ref

$1.24^{* *}[1.05,1.48]$

Ref

$0.94[0.79,1.11]$

Ref

$1.01[0.81,1.25]$

$1.37^{* * *}[1.13,1.66]$

Ref

$0.95[0.69,1.30]$

$1.42 *[0.98,2.03]$

$1.08[0.74,1.58]$

Ref

$0.89[0.72,1.10]$

$0.64^{* * *}[0.48,0.86]$

Ref

$0.64^{* * *}[0.52,0.80]$

$0.43^{* * *}[0.34,0.56]$
Ref

$0.66[0.26,1.65]$

$1.83^{* *}[1.12,2.99]$

Ref

$1.92^{* * *[1.21,3.06]}$

$2.20^{* * *}[1.46,3.31]$

Ref

$2.34^{* * *[1.75,3.13]}$

$2.35^{* * *}[1.56,3.53]$

Ref

$0.77^{*}[0.59,1.01]$

$0.97[0.66,1.43]$

Ref

$0.99[0.76,1.29]$

Ref

1.19[0.91, 1.55]

Ref

$1.08[0.83,1.39]$

Ref

$0.80[0.58,1.11]$

$1.47^{* * *}[1.10,1.97]$

Ref

$0.95[0.63,1.43]$

$0.67[0.15,2.94]$

$0.98[0.61,1.57]$

Ref

$0.78[0.57,1.07]$

$0.59^{* *}[0.37,0.94]$

Ref

$0.59^{* * *}[0.44,0.79]$

$0.39^{* * *}[0.27,0.56]$
Table 2 Logistic regression results of disability and functional

\begin{tabular}{|c|c|c|}
\hline \multirow[t]{2}{*}{ Characteristics } & $\begin{array}{l}\text { Abused since } \\
60 \text { years old }\end{array}$ & $\begin{array}{l}\text { Abused in last } \\
\text { one month }\end{array}$ \\
\hline & OR $(95 \% \mathrm{Cl})$ & OR $(95 \% \mathrm{Cl})$ \\
\hline Fourth & $0.35^{* * *}[0.27,0.46]$ & $0.34^{* * *}[0.23,0.50]$ \\
\hline Richest & $0.30^{* * *}[0.22,0.40]$ & $0.29^{* * *}[0.18,0.48]$ \\
\hline \multicolumn{3}{|l|}{ State } \\
\hline Himachal Pradesh & Ref & Ref \\
\hline Punjab & $0.87[0.62,1.24]$ & $0.28^{*}[0.07,1.03]$ \\
\hline West Bengal & $0.52^{* * *}[0.38,0.71]$ & $1.48[0.82,2.68]$ \\
\hline Orissa & $0.55^{* * *}[0.41,0.74]$ & $0.83[0.43,1.59]$ \\
\hline Maharashtra & $3.71^{* * *}[2.93,4.69]$ & $23.45^{* * *}[14.32,38.40]$ \\
\hline Kerala & $0.41^{* * *}[0.28,0.61]$ & $1.01[0.47,2.15]$ \\
\hline Tamil Nadu & $0.15^{* * *}[0.09,0.24]$ & $0.43^{*}[0.18,1.02]$ \\
\hline
\end{tabular}
health with elder abuse, BKPAl, 2011 (Continued)

efficiently, which generates stress in the household and demands care from other family members, thereby increasing the risk of abuse or mistreatment. Studies have observed higher degree of abuse by care providers of elders suffering from dementia mainly as a result of caregiver stress [22, 36, 49-51].

It is also important to observe that the elderly, especially women and those who residing in urban areas are at higher risk of elder abuse than their rural counterparts. Previous studies have shown that women with disability are at higher risk of elder abuse than men [52-54]. This indicates the gender vulnerability in reference to elder abuse in India. Previous studies have suggested that women experience greater health problems such as disability, functional limitations and psychological distress than men [55, 56]. In addition, widowhood is one of the important contributors to poor health outcomes [57] as a larger share of women are widows and experience longer durations of widowhood in old age. As a result of this, women in old age are more likely to depend on others for financial support and experience poor mental health status. Due to a wider age gap between husband and wife, most women experience old age as widows. Previous studies conducted in India have shown that widowed women are at high risk of experiencing violence and abuse [58]. The gender gap in employment in old age is also important to note. Elderly women in India are less likely to be employed [59], which increases their financial dependency and elder abuse [60]. Furthermore, the elderly in urban areas are at higher risk of elder abuse than their rural counterparts. The results are consistent with previous 
Table 3 Logistic regression results of elder abuse stratified by gender differences, BKPAI, 2011

\begin{tabular}{|c|c|c|c|c|}
\hline \multirow[t]{3}{*}{ Characteristics } & \multicolumn{2}{|c|}{ Abused since 60 years old } & \multicolumn{2}{|c|}{ Abused in last one month } \\
\hline & Male & Female & Male & Female \\
\hline & OR (95\% Cl) & OR (95\% Cl) & OR (95\% Cl) & OR (95\% Cl) \\
\hline \multicolumn{5}{|l|}{ ADL } \\
\hline No ADL & Ref & Ref & Ref & Ref \\
\hline $1 \mathrm{ADL}$ & $0.89[0.41,1.90]$ & $1.06[0.55,2.05]$ & $0.50[0.10,2.32]$ & $0.81[0.25,2.61]$ \\
\hline $2+A D L$ & $1.60 *[0.99,2.59]$ & $1.14[0.75,1.74]$ & $2.81^{* * *}[1.37,5.78]$ & $1.41[0.71,2.81]$ \\
\hline \multicolumn{5}{|l|}{ IADL } \\
\hline No IADL & Ref & Ref & Ref & Ref \\
\hline 1 IADL & $1.07[0.67,1.71]$ & $1.40^{* *}[0.92,2.13]$ & $1.92^{*}[0.96,3.81]$ & $1.83 *[0.96,3.49]$ \\
\hline $2+\operatorname{IADL}$ & $1.22[0.81,1.83]$ & $1.47^{* *}[1.03,2.10]$ & $1.69 *[0.92,3.13]$ & $2.56^{* *}[1.46,4.49]$ \\
\hline \multicolumn{5}{|l|}{ Disability } \\
\hline No disability & Ref & Ref & Ref & Ref \\
\hline 1 disability & $1.70^{* * *}[1.27,2.28]$ & $2.18^{* * *}[1.68,2.84]$ & $2.12^{* * *}[1.36,3.29]$ & $2.63^{* * *}[1.77,3.90]$ \\
\hline $2+$ disability & $1.85^{* * *}[1.23,2.77]$ & $3.16^{* *}[2.22,4.49]$ & $1.72 *[0.92,3.22]$ & $3.18^{* * *}[1.83,5.50$ \\
\hline \multicolumn{5}{|l|}{ Age } \\
\hline $60-69$ & Ref & Ref & Ref & Ref \\
\hline $70-79$ & $0.95[0.74,1.23]$ & $0.84[0.66,1.07]$ & $0.76[0.51,1.14]$ & $0.72 *[0.49,1.05]$ \\
\hline $80+$ & $1.56^{* *}[1.10,2.21]$ & $0.86[0.61,1.21]$ & $1.07[0.59,1.92]$ & $0.85[0.50,1.42]$ \\
\hline \multicolumn{5}{|l|}{ Marital status } \\
\hline Married & Ref & Ref & Ref & Ref \\
\hline Others & $1.04[0.79,1.39]$ & $1.34^{* * *}[1.07,1.68]$ & $0.89[0.56,1.42]$ & $1.34^{*}[0.96,1.88]$ \\
\hline \multicolumn{5}{|l|}{ Caste } \\
\hline SC/ST & Ref & Ref & Ref & Ref \\
\hline $\mathrm{OBC}$ & $1.17[0.85,1.60]$ & $0.88[0.65,1.18]$ & $1.15[0.71,1.87]$ & $0.56^{* *}[0.36,0.88]$ \\
\hline Others & $1.38^{* *}[1.03,1.84]$ & $1.39^{* *}[1.07,1.80]$ & $1.77^{* *}[1.12,2.78]$ & $1.32[0.89,1.95]$ \\
\hline \multicolumn{5}{|l|}{ Religion } \\
\hline Hindu & Ref & Ref & Ref & Ref \\
\hline Muslim & $1.01[0.63,1.62]$ & $0.89[0.58,1.36]$ & $1.11[0.62,2.00]$ & $0.84[0.47,1.50]$ \\
\hline Sikh & $1.74^{* *}[1.01,2.97]$ & $1.23[0.75,2.00]$ & $0.37[0.03,3.99]$ & $1.06[0.15,7.16]$ \\
\hline Others & $0.67[0.34,1.31]$ & $1.43[0.89,2.29]$ & $0.60[0.25,1.42]$ & $1.20[0.66,2.17]$ \\
\hline \multicolumn{5}{|l|}{ Schooling } \\
\hline $0-4$ years & Ref & Ref & Ref & Ref \\
\hline $5-9$ years & $1.01[0.77,1.32]$ & $0.76[0.54,1.06]$ & $0.77[0.50,1.17]$ & $0.83[0.51,1.35]$ \\
\hline $10+$ years & $0.72 *[0.51,1.03]$ & $0.43^{* * *}[0.23,0.77]$ & $0.63[0.36,1.11]$ & $0.39 *[0.13,1.18]$ \\
\hline \multicolumn{5}{|l|}{ Wealth quintile } \\
\hline Poorest & Ref & Ref & Ref & Ref \\
\hline Second & $0.58^{* * *}[0.42,0.81]$ & $0.67 * * *[0.50,0.89]$ & $0.62 *[0.39, .96]$ & $0.56^{* * *}[0.38,0.84]$ \\
\hline Middle & $0.41^{* * *}[0.29,0.59]$ & $0.42^{* * *}[0.31,0.59]$ & $0.37^{* * *}[0.22, .63]$ & $0.44^{* * *}[0.28,0.69]$ \\
\hline Fourth & $0.35^{* * *}[0.24,0.51]$ & $0.33^{* * *}[0.23,0.46]$ & $0.34^{* * *}[0.19, .61]$ & $0.33^{* * *}[0.20,0.53]$ \\
\hline Richest & $0.30^{* * *}[0.19,0.46]$ & $0.28^{* * *}[0.19,0.42]$ & $0.29^{* * *}[0.14,0.59]$ & $0.31^{* * *}[0.16,0.58]$ \\
\hline \multicolumn{5}{|l|}{ State } \\
\hline Himachal Pradesh & Ref & Ref & Ref & Ref \\
\hline Punjab & $0.81[0.48,1.36]$ & $0.92[0.58,1.48]$ & $0.52[0.08,3.09]$ & $0.17 *[0.02,1.09]$ \\
\hline West Bengal & $0.59 * *[0.38,0.92]$ & $0.46^{* * *}[0.30,0.71]$ & $1.90[0.78,4.63]$ & $1.21[0.55,2.66]$ \\
\hline Orissa & $0.53^{* * *}[0.34,0.81]$ & $0.55^{* * *}[0.36,0.84]$ & $1.15[0.45,2.93]$ & $0.61[0.24,1.51]$ \\
\hline Maharashtra & $3.53^{* * *}[2.52,4.94]$ & $3.78^{* * *}[2.72,5.24]$ & $24.11^{* * *}[11.3,51.24]$ & $23.23^{* * *}[12.0,44.6]$ \\
\hline Kerala & $0.29 * * *[0.15,0.56]$ & $0.53^{* *}[0.32,0.87]$ & $0.93[0.27,3.24]$ & $1.14[0.43,3.01]$ \\
\hline Tamil Nadu & $0.13^{* * *}[0.06,0.27]$ & $0.16^{* * *}[0.89,0.30]$ & $0.25 *[0.05,1.24]$ & $0.57[0.19,1.64]$ \\
\hline
\end{tabular}

OR Odds Ratio, Ref reference; ${ }^{* * *}$ Significant at $p<.001,{ }^{* *}$ Significant at $p<.005,{ }^{*}$ Significant at $p<.01$ 
Table 4 Logistic regression results of elder abuse stratified by place of residence, BKPAl, 2011

\begin{tabular}{|c|c|c|c|c|}
\hline \multirow[b]{3}{*}{ Characteristics } & \multicolumn{2}{|c|}{ Abused since 60 years old } & \multicolumn{2}{|c|}{ Abuse in last one month } \\
\hline & Rural & Urban & Rural & Urban \\
\hline & OR $(95 \% \mathrm{Cl})$ & OR $(95 \% \mathrm{Cl})$ & OR $(95 \% \mathrm{Cl})$ & OR $(95 \% \mathrm{Cl})$ \\
\hline \multicolumn{5}{|l|}{$\mathrm{ADL}$} \\
\hline No ADL & Ref & Ref & Ref & Ref \\
\hline $1 \mathrm{ADL}$ & $0.60[0.28,1.30]$ & $1.06[0.81,3.13]$ & $0.37[0.08,1.72]$ & $1.08[0.32,3.67]$ \\
\hline $2+\mathrm{ADL}$ & $1.46^{*}[0.98,2.16]$ & $1.13[0.67,1.91]$ & $2.46^{* * *}[1.34,4.51]$ & $1.03[0.42,2.51]$ \\
\hline \multicolumn{5}{|l|}{ IADL } \\
\hline No IADL & Ref & Ref & Ref & Ref \\
\hline $1 \mathrm{IADL}$ & $1.08[0.70,1.67]$ & $1.47^{*}[0.94,2.28]$ & $1.56[0.80,3.04]$ & $2.24^{* *}[1.15,4.34]$ \\
\hline $2+\mid A D L$ & $1.38^{*}[0.95,1.99]$ & $1.29[0.87,1.92]$ & $2.14^{* * *}[1.21,3.77]$ & $2.17^{* *}[1.18,3.99]$ \\
\hline \multicolumn{5}{|l|}{ Disability } \\
\hline No disability & Ref & Ref & Ref & Ref \\
\hline 1 disability & $1.56^{* * *}[1.21,2.01]$ & $2.63^{* * *}[1.94,3.57]$ & $2.00^{* * *}[1.36,2.94]$ & $2.90^{* * *}[1.84,4.57]$ \\
\hline $2+$ disability & $1.85^{* * *}[1.28,2.67]$ & $3.49^{* * *}[2.38,5.13]$ & $1.91^{* *}[1.08,3.37]$ & $3.07^{* * *}[1.67,5.65]$ \\
\hline \multicolumn{5}{|l|}{ Age } \\
\hline $60-69$ & Ref & Ref & & \\
\hline $70-79$ & $0.80^{*}[0.64,1.00]$ & $1.12[0.84,1.49]$ & $0.64^{* *}[0.45,0.92]$ & $1.00[0.65,1.54]$ \\
\hline $80+$ & $1.08[0.79,1.47]$ & $1.28[0.86,1.90]$ & $0.99[0.60,1.63]$ & $0.99[0.52,1.86]$ \\
\hline \multicolumn{5}{|l|}{ Sex } \\
\hline Male & Ref & Ref & Ref & Ref \\
\hline Female & $0.92[0.74,1.14]$ & $0.96[0.72,1.27]$ & $1.00[0.71,1.41]$ & $0.99[0.65,1.53]$ \\
\hline \multicolumn{5}{|l|}{ Marital status } \\
\hline Married & Ref & Ref & Ref & Ref \\
\hline Others & $1.34^{* * *}[1.08,1.66]$ & $1.11[0.83,1.47]$ & $1.30[0.92,1.82]$ & $1.07[0.70,1.63]$ \\
\hline \multicolumn{5}{|l|}{ Caste } \\
\hline SC/ST & Ref & Ref & Ref & Ref \\
\hline $\mathrm{OBC}$ & $0.99[0.75,1.29]$ & $1.08[0.75,1.55]$ & $0.74[0.49,1.12]$ & $0.94[0.55,1.60]$ \\
\hline Others & $1.36^{* *}[1.07,1.73]$ & $1.46^{* *}[1.05,2.02]$ & $1.51^{* *}[1.04,2.20]$ & $1.60^{*}[0.98,2.61]$ \\
\hline \multicolumn{5}{|l|}{ Religion } \\
\hline Hindu & Ref & Ref & Ref & Ref \\
\hline Muslim & $0.92[0.58,1.48]$ & $0.95[0.61,1.48]$ & $0.76[0.38,1.52]$ & $1.08[0.63,1.85]$ \\
\hline Sikh & $2.13^{* * *}[1.22,3.73]$ & $1.11[0.65,1.91]$ & $0.32[0.02,4.20]$ & $1.17[0.19,7.24]$ \\
\hline Others & $1.28[0.75,2.17]$ & $0.95[0.54,1.66]$ & $1.23[0.64,2.35]$ & $0.83[0.39,1.74]$ \\
\hline \multicolumn{5}{|l|}{ Schooling } \\
\hline $0-4$ years & Ref & Ref & Ref & Ref \\
\hline 5-9 years & $1.02[0.77,1.35]$ & $0.75^{* *}[0.55,1.03]$ & $0.89[0.57,1.38]$ & $0.68[0.43,1.07]$ \\
\hline $10+$ years & $0.75[0.48,1.17]$ & $0.55^{* * *}[0.37,0.82]$ & $0.50[0.21,1.18]$ & $0.59^{*}[0.32,1.06]$ \\
\hline \multicolumn{5}{|l|}{ Wealth quintile } \\
\hline Poorest & Ref & Ref & Ref & Ref \\
\hline Second & $0.63^{* * *}[0.49,0.81]$ & $0.69[0.44,1.09]$ & $0.60^{* * *}[0.42, .85]$ & $0.64[0.34,1.17]$ \\
\hline Middle & $0.40^{* * *}[0.29,0.56]$ & $0.52^{* * *}[0.34,0.81]$ & $0.47^{* * *}[0.29,0.77]$ & $0.37^{* * *}[0.20,0.68]$ \\
\hline Fourth & $0.34^{* * *}[0.23,0.48]$ & $0.40^{* * *}[0.26,0.63]$ & $0.35^{* * *}[0.19,0.63]$ & $0.36^{* * *}[0.19,0.67]$ \\
\hline Richest & $0.30^{* * *}[0.19,0.47]$ & $0.33^{* * *}[0.20,0.53]$ & $0.31^{* *}[0.12,0.79]$ & $0.30^{* * *}[0.15,0.59]$ \\
\hline
\end{tabular}


Table 4 Logistic regression results of elder abuse stratified by place of residence, BKPAl, 2011 (Continued)

\begin{tabular}{|c|c|c|c|c|}
\hline \multirow[b]{3}{*}{ Characteristics } & \multicolumn{2}{|c|}{ Abused since 60 years old } & \multicolumn{2}{|c|}{ Abuse in last one month } \\
\hline & Rural & Urban & Rural & Urban \\
\hline & OR $(95 \% \mathrm{Cl})$ & OR $(95 \% \mathrm{Cl})$ & OR $(95 \% \mathrm{Cl})$ & OR $(95 \% \mathrm{Cl})$ \\
\hline Himachal Pradesh & Ref & Ref & Ref & Ref \\
\hline Punjab & $0.53^{* *}[0.30,0.93]$ & $1.29[0.79,2.09]$ & $0.40[0.06,2.65]$ & $0.25[0.04,1.46]$ \\
\hline West Bengal & $0.48^{* * *}[0.32,0.72]$ & $0.64^{*}[0.38,1.05]$ & $1.47[0.67,3.23]$ & $1.74[0.69,4.37]$ \\
\hline Orissa & $0.53^{* * *}[0.36,0.77]$ & $0.60^{*}[0.36,1.00]$ & $1.22[0.55,2.71]$ & $0.38[0.10,1.35]$ \\
\hline Maharashtra & $3.23^{* * *}[2.40,4.36]$ & $4.85^{* * *}[3.25,7.24]$ & $24.5^{* * *}[13.0,46.4]$ & $24.75^{* * *}[11.0,55.2]$ \\
\hline Kerala & $0.31^{* * *}[0.18,0.53]$ & $0.61[0.33,1.10]$ & $0.92[0.32,2.57]$ & $1.19[0.37,3.77]$ \\
\hline Tamil Nadu & $0.17^{* * *}[0.10,0.30]$ & $0.10^{* * *}[0.39,0.28]$ & $0.37[0.11,1.22]$ & $0.58[0.15,2.15]$ \\
\hline
\end{tabular}

OR Odds Ratio, Ref reference; ${ }^{* *}$ Significant at $p<.001,{ }^{*}$ Significant at $p<.005,{ }^{*}$ Significant at $p<.01$

studies which have suggested that the urban elderly are at higher risk of abuse [61].

In this study, the association between socioeconomic status and elder abuse is significant and negative, which is consistent with previous literature [18, 52]. Studies have shown that socioeconomic status plays an important role in several ways which may prevent elder abuse [19]. A study conducted in Tamil Nadu has pointed out a significant protective impact of the wealth index on elder abuse [15]. Another study conducted in South Korea has reflected similar results [52].

The results of this study highlight the role of disability and functional limitations and elder abuse highlighting the significance of functional ability. While the prevalence of disability and ADL limitations increases with age, the negative consequences associated with disability highlight the need for healthcare to address the problem more efficiently. Further, the study identifies the subset of vulnerable population. The association differs by place of residence and gender. This study identifies women as the more vulnerable population in India than men. This may be partly due to the age difference between husband and wife leading to women living for more years as widows. Chances of men living as widowers is less likely. This may result in higher risk of elder abuse of women $[18,62]$.

\section{Strengths}

To our knowledge, this is the first study to examine the role of multiple disabilities and functional limitations on elder abuse in India. The association of disability and functional limitations with abuse is consistent and strong. Most of the previous studies have used ever experience of abuse/mistreatment. In this study, we use the conditions of ever experience of abuse and current experience of abuse. It is important to note that $6 \%$ of elderly in India experienced abuse in the month preceding the survey. In this context, a more detailed investigation of abuse is important. Furthermore, the study uses nationally representative data. Therefore, the results can be generalized at the national level.

\section{Limitation of the study}

Elder abuse record is self-reported which may have some response bias. This reporting bias could also affect the result. It is also notable that the assessment of elder abuse is based on a single question. Furthermore, most of the previous studies have used past year prevalence of elder abuse and our study covered lifetime (since participants turned 60 years old) duration as well as abuse in last 1 month. Therefore this study has some limitation while comparing with other studies. This study included only the overall prevalence of abuse and abuse in last 1 month with yes or no options. The severity of the abuse was not captured in the survey [63]. Furthermore, the result is based on only selected states of India. In this perspective, more research is needed to understand the prevalence and correlates of elder abuse across states of India. Additionally, the result of this study is based on cross-sectional data. Therefore, any causal relationship cannot established.

\section{Conclusions}

Elder abuse is a human rights issue and preventing it necessary to improve the overall wellbeing of the growing elderly population in India. In this study, elder abuse is linked with disability and functional limitation among the elderly in India. The association is particularly stronger among women and urban residents. It suggests the differences in the association across population subgroups. Elder abuse violates the social norms of respecting elders. Disability and multi-disability are strongly associated with elder abuse. In this context, it is necessary to improve the recognition of elder abuse as a public health concern. Also, it is important to improve 
research to understand the factors involved in elder abuse and to develop strategies for its prevention. Furthermore, the government's welfare and protection measures and programmes should support elders with disability. The immediate need is to properly protect disabled elders from abuse.

\section{Abbreviations}

ADL: Activities of daily living; BKPAl: Building Knowledge Base on Population Ageing in India; Cl: Confidence interval; IADL: Instrumental activities of daily living; OBC: Other Backward Class; OR: Odds ratio; SC: Scheduled caste; UNFPA: United Nations Population Fund

\section{Acknowledgements}

The authors thankful to Prof.R.Nagarajan and Mr. Selvamani for their support during preparation of the manuscript.

\section{Authors' contributions}

T.S designed and performed the analysis and wrote the first draft. T. S did the statistical analysis, reviewed and approved the final version of the manuscript. R. P provided substantial feedback on the manuscript. T. S and R. $P$ reviewed and approved the final version of the manuscript.

\section{Funding}

The authors received no specific funding for this work.

\section{Availability of data and materials}

The data-sets used in the present study are available from the corresponding author on request.

\section{Ethics approval and consent to participate}

Ethical approval for this study, involving secondary data analyses, has been obtained from the Ethics Committee in the University of Southampton. Informed written consent was obtained from each participant, who were ensured that data would remain confidential and used for research purposes only.

\section{Consent for publication}

Not applicable.

\section{Competing interests}

The authors declare that they have no competing interests.

\section{Author details}

'Department of Development Studies, International Institute for Population Sciences, Govandi Station Road, Mumbai 400088, India. ${ }^{2}$ Arora Health Initiative, Bangalore, India.

Received: 11 February 2020 Accepted: 15 June 2020

Published online: 23 June 2020

\section{References}

1. World Health Organization. A global response to elder abuse and neglect: building primary health care capacity to deal with the problem worldwide: main report. Geneva: World Health Organization; 2008.

2. Collins KA. Elder maltreatment: a review. Arch Pathol Lab Med. 2006:130: 1290-6.

3. Stobo JD, Salmon ME, Cohn F. Confronting chronic neglect: the education and training of health professionals on family violence: National Academies Press; 2002.

4. Chokkanathan S, Lee AE. Elder mistreatment in urban India: a community based study. Journal of Elder Abuse \& Neglect. 2006;17(2):45-61.

5. Evandrou M, Falkingham JC, Qin M, Vlachantoni A. Elder abuse as a risk factor for psychological distress among older adults in India: a crosssectional study. BMJ Open. 2017;7(10):e017152.

6. Wong JS, Waite LJ. Elder mistreatment predicts later physical and psychological health: results from a national longitudinal study. J Elder Abuse Neglect. 2017;29(1):15-42.
7. Dong X, Simon M, De Leon CM, Fulmer T, Beck T, Hebert L, Dyer C, Paveza $\mathrm{G}$, Evans D. Elder self-neglect and abuse and mortality risk in a communitydwelling population. Jama. 2009;302(5):517-26.

8. Dong XQ, Simon MA, Beck TT, Farran C, McCann JJ, De Leon CM, Laumann E, Evans DA. Elder abuse and mortality: the role of psychological and social wellbeing. Gerontology. 2011;57(6):549-58.

9. Lachs MS, Williams CS, O'brien S, Pillemer KA, Charlson ME. The mortality of elder mistreatment. Jama. 1998;280(5):428-32.

10. Dong $X$, Simon MA. Elder abuse as a risk factor for hospitalization in older persons. JAMA Intern Med. 2013;173(10):911-7.

11. Ahmad M, Lachs MS. Elder abuse and neglect: what physicians can and should do. Cleve Clin J Med. 2002;69(10):801-8.

12. Shields LB, Hunsaker DM, Hunsaker JC. Abuse and neglect: a ten-year review of mortality and morbidity in our elders in a large metropolitan area. J Forensic Sci. 2003:49(1):1-6.

13. Dong X, Chen R, Chang ES, Simon M. Elder abuse and psychological wellbeing: a systematic review and implications for research and policy-a mini review. Gerontology. 2013;59(2):132-42.

14. Yon Y, Mikton CR, Gassoumis ZD, Wilber KH. Elder abuse prevalence in community settings: a systematic review and meta-analysis. Lancet Glob Health. 2017:5(2):e147-56.

15. Chokkanathan S. Factors associated with elder mistreatment in rural Tamil Nadu, India: a cross-sectional survey. Int J Geriatric Psychiatry. 2014;29(8): 863-9.

16. Dong XQ. Elder abuse: systematic review and implications for practice. J Am Geriatr Soc. 2015;63(6):1214-38.

17. Melchiorre MG, Chiatti C, Lamura G, Torres-Gonzales F, Stankunas M, Lindert J, loannidi-Kapolou E, Barros H, Macassa G, Soares JF. Social support, socioeconomic status, health and abuse among older people in seven European countries. PLoS One. 2013;8(1):e54856.

18. Skirbekk V, James KS. Abuse against elderly in India-the role of education. BMC Public Health. 2014;14(1):336.

19. Wu L, Chen H, Hu Y, Xiang H, Yu X, Zhang T, Cao Z, Wang Y. Prevalence and associated factors of elder mistreatment in a rural community in People's Republic of China: a cross-sectional study. PLoS One. 2012;7(3): e33857.

20. Habjanič A, Lahe D. Are frail older people less exposed to abuse in nursing homes as compared to community-based settings? Statistical analysis of Slovenian data. Arch Gerontol Geriatr. 2012;54(3):e261-70.

21. Torres-Castro S, Szlejf C, Parra-Rodríguez L, Rosas-Carrasco O. Association between frailty and elder abuse in community-dwelling older adults in Mexico City. J Am Geriatr Soc. 2018;66(9):1773-8.

22. Cooper C, Selwood A, Blanchard M, Walker Z, Blizard R, Livingston G. Abuse of people with dementia by family carers: representative cross sectional survey. BMj. 2009;338:b155.

23. Dong X, Chang ES, Wong E, Wong B, Simon MA. Association of depressive symptomatology and elder mistreatment in a US Chinese population: findings from a community-based participatory research study. J Aggress Maltreat Trauma. 2014;23(1):81-98.

24. Dong X, Chen R, Fulmer T, Simon MA. Prevalence and correlates of elder mistreatment in a community-dwelling population of US Chinese older adults. J Aging Health. 2014;26(7):1209-24.

25. Giraldo-Rodríquez L, Rosas-Carrasco O. Development and psychometric properties of the geriatric mistreatment scale. Geriatr Gerontol Int. 2013; 13(2):466-74.

26. Pillemer K, Burnes D, Riffin C, Lachs MS. Elder abuse: global situation, risk factors, and prevention strategies. Gerontologist. 2016;56(Suppl_2):S194-205.

27. Roepke-Buehler SK, Simon M, Dong X. Association between depressive symptoms, multiple dimensions of depression, and elder abuse: a crosssectional, population-based analysis of older adults in urban Chicago. J Aging Health. 2015;27(6):1003.

28. Lachs MS, Berkman L, Fulmer T, Horwitz RI. A prospective community-based pilot study of risk factors for the investigation of elder mistreatment. J Am Geriatr Soc. 1994;42(2):169-73.

29. Giraldo-Rodríguez L, Rosas-Carrasco O, Mino-León D. Abuse in Mexican older adults with long-term disability: national prevalence and associated factors. J Am Geriatr Soc. 2015;63(8):1594-600.

30. Faustino AM, Gandolfi L, Moura LB. Functional capability and violence situations against the elderly. Acta Paulista de Enfermagem. 2014;27(5):392-8.

31. Burnes D, Pillemer K, Caccamise PL, Mason A, Henderson CR Jr, Berman J, Cook AM, Shukoff D, Brownell P, Powell M, Salamone A. Prevalence of and 
risk factors for elder abuse and neglect in the community: a populationbased study. J Am Geriatr Soc. 2015;63(9):1906-12.

32. Laumann EO, Leitsch SA, Waite LJ. Elder mistreatment in the United States: prevalence estimates from a nationally representative study. J Gerontol Ser B Psychol Sci Soc Sci. 2008;63(4):S248-54.

33. Lee M. Caregiver stress and elder abuse among Korean family caregivers of older adults with disabilities. J Fam Violence. 2008;23(8):707.

34. Acierno R, Hernandez MA, Amstadter AB, Resnick HS, Steve K, Muzzy W, Kilpatrick DG. Prevalence and correlates of emotional, physical, sexual, and financial abuse and potential neglect in the United States: the National Elder Mistreatment Study. Am J Public Health. 2010;100(2):292-7.

35. Amstadter AB, Zajac K, Strachan M, Hernandez MA, Kilpatrick DG, Acierno R. Prevalence and correlates of elder mistreatment in South Carolina: the South Carolina elder mistreatment study. J Interpers Violence. 2011;26(15): 2947-72.

36. Johannesen M, LoGiudice D. Elder abuse: a systematic review of risk factors in community-dwelling elders. Age Ageing. 2013:42(3):292-8.

37. Johnson NE. The racial crossover in comorbidity, disability, and mortality. Demography. 2000;37(3):267-83.

38. Cooper C, Selwood A, Blanchard M, Walker Z, Blizard R, Livingston G. The determinants of family carers' abusive behaviour to people with dementia: results of the CARD study. J Affect Disord. 2010;121(1-2):136-42.

39. Lee $\mathrm{M}$, Kolomer S. Caregiver burden, dementia, and elder abuse in South Korea. J Elder Abuse Negl. 2005;17(1):61-74.

40. World Health Organization. World report on ageing and health. Geneva: World Health Organization; 2015. ISBN: 9789241565042.

41. Kelley-Moore JA, Schumacher JG, Kahana E, Kahana B. When do older adults become "disabled"? Social and health antecedents of perceived disability in a panel study of the oldest old. J Health Soc Behav. 2006;47(2):126-41.

42. Mawar S, Koul P, Das S, Gupta S. Association of physical problems and depression with elder abuse in an urban community of North India. Indian J Community Med. 2018:43(3):165.

43. Patel VK, Tiwari DS, Shah VR, Patel MG, Raja HH, Patel DS. Prevalence and predictors of abuse in elderly patients with depression at a tertiary care Centre in Saurashtra, India. Indian J Psychol Med. 2018;40(6):528.

44. Chaurasia H, Srivastava S. Abuse, neglect, and disrespect against older adults in India. J Popul Ageing. 2020;18:1-5.

45. United Nations. World population prospects: the 2015 revision. United Nations Econ Soc Aff. 2015;33(2):1-66.

46. Alam M, James KS, Gridhar G, Sathyanarayana KM, Kumar S, Raju SS, Syamala TS, Subaiya L, Bansod DW. Report on the status of elderly in select states of India, 2011. New Delhi: United Nations Population Fund; 2012.

47. Bao J, Chua KC, Prina M, Prince M. Multimorbidity and care dependence in older adults: a longitudinal analysis of findings from the 10/66 study. BMC Public Health. 2019:19(1):585.

48. Fried TR, Bradley EH, Williams CS, Tinetti ME. Functional disability and health care expenditures for older persons. Arch Intern Med. 2001;161(21):2602-7.

49. Yan E. Abuse of older persons with dementia by family caregivers: results of a 6-month prospective study in Hong Kong. Int J Geriatric Psychiatry. 2014; 29(10):1018-27.

50. Fang B, Yan E. Abuse of older persons with dementia: a review of the literature. Trauma Violence Abuse. 2018;19(2):127-47.

51. Yan E, Kwok T. Abuse of older Chinese with dementia by family caregivers: an inquiry into the role of caregiver burden. Int J Geriatric Psychiatry. 2011; 26(5):527-35.

52. Jeon GS, Cho SI, Choi K, Jang KS. Gender differences in the prevalence and correlates of elder abuse in a community-dwelling older population in Korea. Int J Environ Res Public Health. 2019;16(1):100.

53. Kreigsman $\mathrm{KH}$, Bregman $\mathrm{S}$. Women with disabilities at midlife. Rehabilitation Counseling Bulletin; 1985.

54. Nosek MA, Howland CA, Hughes RB. The investigation of abuse and women with disabilities: going beyond assumptions. Violence Against Women. 2001;7(4):477-99.

55. Bora JK, Saikia N. Gender differentials in self-rated health and self-reported disability among adults in India. PLoS One. 2015;10(11):e0141953.

56. Kastor A, Mohanty SK. Associated covariates of functional limitation among older adults in India: an exploration. Ageing Int. 2016;41(2):178-92.

57. Perkins JM, Lee HY, James KS, Oh J, Krishna A, Heo J, Lee JK, Subramanian SV. Marital status, widowhood duration, gender and health outcomes: a cross-sectional study among older adults in India. BMC Public Health. 2016; 16(1):1032.
58. Gupta SK, Sekher TV. Are Elderly Widows More Vulnerable to Abuse and Violence? Findings from Jharkhand, India. InAbuse and Neglect of the Elderly in India. Singapore: Springer; 2018. p. 139-56.

59. Visaria A, Dommaraju P. Productive aging in India. Soc Sci Med. 2019;229: $14-21$.

60. Kumar P, Patra S. A study on elder abuse in an urban resettlement colony of Delhi. J Family Med Primary Care. 2019;8(2):621.

61. Kaur J, Kaur J, Sujata N. Comparative study on perceived abuse and social neglect among rural and urban geriatric population. Indian J Psychiatry. 2015;57(4):375.

62. Madhurima M. Elderly widows as victims of physical abuse: a qualitative study in the state of Punjab. Indian J Gerontol. 2008;22:501-14.

63. Burnes D, Pillemer K, Lachs MS. Elder abuse severity: a critical but understudied dimension of victimization for clinicians and researchers. The Gerontologist. 2017;57(4):745-56.

\section{Publisher's Note}

Springer Nature remains neutral with regard to jurisdictional claims in published maps and institutional affiliations.

Ready to submit your research? Choose BMC and benefit from:

- fast, convenient online submission

- thorough peer review by experienced researchers in your field

- rapid publication on acceptance

- support for research data, including large and complex data types

- gold Open Access which fosters wider collaboration and increased citations

- maximum visibility for your research: over $100 \mathrm{M}$ website views per year

At BMC, research is always in progress.

Learn more biomedcentral.com/submissions 